\title{
Antimicrobial Activities of Extract of Andalas Endophytic Bacterial Fermentation Products in Overcoming Oral Cavity Infection
}

\author{
Dwi Hilda Putri $^{1 *}$ Ratih Rahayu$^{1}$, Dinda Sahara ${ }^{2}$, Nurhelmi ${ }^{1}$, Violita ${ }^{1}$
}

Department of Biology, Faculty of Mathematics and Natural Science (FMIPA), Universitas Negeri Padang, Indonesia

Department of Chemistry, Faculty of Mathematics and Natural Science (FMIPA)

Universitas Negeri Padang, Indonesia

Dwihildaputri.08@gmail.com

\begin{abstract}
Dental and oral infection problems can be overcome using natural antimicrobial compounds from bacterial endophytic resulted from bacterial fermentation. This study aims to determine the effectiveness of extracts of Andalas endophytic bacterial fermentation products in treating oral cavity infections. Fermentation products was extracted using maceration methods. Antimicrobial activity of Andalas endophytic bacterial fermentation product was evaluated to $\mathrm{S}$. mutans and $\mathrm{C}$. albicans by disk diffusion method. The study showed that the optimum concentration of extract in inhibiting microbial growth that causes oral cavity infections was at $12.5 \%$.
\end{abstract}

Keywords: oral cavity infections, endophytic Andalas, antimicrobial

\section{Introduction}

The oral cavity is one of the most vulnerable places in the body to get infected. According to the Rikerdas National Survey in 2013,The disorders of the oral cavity include stomatitis, gingivitis, and tooth keries, there was an increasing in cases of Indonesian residents who had dental and oral health problems, where in 2013 there were cases of $25.9 \%$, while in 2007 they were only $23.2 \%$. The disorder can be caused by normal microorganisms in the oral cavity, both bacteria and fungi.

Streptococcus mutans (S.mutans) and Candida albicans (C.albicans) are two types of microorganisms commonly found in the oral cavity as a cause of infection. According to Farkash (2019)[1], S. mutans is a facultative anaerobic gram-positive bacterium found in the oral cavity and in dental biofilms. S. mutans is one of etiological factors of dental caries. In fact, $C$. albicans is an opportunistic fungal pathogen which is mostly found in humans. This can be the causes of candidiasis infection which results mucous membranes[2], and forms biofilms in the mucous membrane as well as in implants[3].

The presence of pathogenic microorganisms can be controlled using antimicrobial compounds. One of effort to get the resources is utilizing endophytic bacteria. Endophytic bacteria are bacteria which live in plant tissues and do not cause infection to the plants[4]. Endophytic bacteria are able to produce secondary metabolites that are similar to their host plants, even in high amounts[5]. One of the host plant of endophytic bacteria is the Andalas 
plant (Morus macroura Miq.). According to Soekamto (2005)[6], Andalas plants are plants that have several antimicrobial active compounds such as morasin $B$, morasin $P$, mulberoside $C$, and mulberoforan. Andalas plants also have several types of derivative compunds such as oxiresveratrol , andalisin A, 2-arilbenzouran derivatives, morasin M, Coumarin derivatives, umbeliferon, and B-resolsilaldehid [6].

Endophytic bacteria producing antimicrobial active compounds have been isolated from several Andalas plant tissues[7]-[9]. Antimicrobial compounds produced by endophytic bacteria can be produced through fermentation. The optimization of several conditions for Andalas endophytic bacteria in producing antimicrobial compounds has been done by Nafion (2018)[10]. This study aims to determine the effectiveness of extract of Andalas endophytic bacterial fermentation products in overcoming microbes that cause infection in the oral cavity.

\section{Experimental Section}

\subsection{Bacterial Isolate}

This research uses two Andalas antimicrobial-producing endophytic bacterial isolates. B.J.T.A.2.1 isolate is used as an antibacterial compound producer[7] and A.T.B.10-6 is used as an antifungal compound producer[9]. As a microbial test, Streptococcus mutant bacteria (isolated from a patient in the FK Microbiology Laboratory of Andalas University) and Candida albicans fungus (isolated from a patient in the FK Microbiology Laboratory of Universitas Sumatera Utara) are used.

\subsection{Production and Extraction of Andalas Endophytic Bacterial Fermentation Product Active Compound}

Production of antimicrobial active compound is carried out by fermentation. Fermentation process by each isolate are performed under different condition, where the B.J.T.A.2.1 isolate is fermented by using Muller Hinton (MH) medium for 20 hours and A.T.B.10-6 isolate is fermented using Lactosa Broth (LB) medium for 12 hours. The fermentation is performed in the incubator shaker at room temperature.

The extraction is done by maceration method. Antimicrobial active compound is macerated from fermentation product of endophytic bacterial using methanol solvent $(1: 1 \mathrm{v} / \mathrm{v})$ for 3 days. Each maceration result is evaporated on the rotary vacum evaporator at $40^{\circ} \mathrm{C}$ until thick extract is obtained.

\subsection{Antimicrobial Activity Test of Extracted Andalas Endophytic Bacterial Fermentation Product}

Antimicrobial activity test is performed using paper disk diffusion method. The extract of the active compound from Andalas endophytic bacterial isolate ATB.10-6 is tested on C.albicans which is grown on PDA medium. Concentration of the extract that used are 6,25\%, 12,5\%, 25\%, and 50\%. Next, the active compound extract from Andalas endophytic bacterial isolat B.J.T.A.2.1 is tested on S.mutants which is grown on MHA medium. Concentration of the extract that used are 3,125\%,6,25\%, 12,5\%, 25\%, and 50\%. As a positive control, use mouthwash liquid (Listerine). Next the culture of the test microba is incubated at temperature $37^{\circ} \mathrm{C}$ for $24-48$ hours. The measurement of inhibits zone that formed is performed by using a caliper. To determine the result of the antimicrobial activity, the antimicrobial activity is 
statistically analyzed by using ANOVA test, and if it's significantly different, proceed with a further DMRT test at 5\% level.

\section{Results and Discussion}

The results show that extracts of Andalas endophytic bacterial fermentation products was able to inhibit the growth of microbes that cause infections in the oral cavity. The inhibition zone formed can be seen in Figure 1.

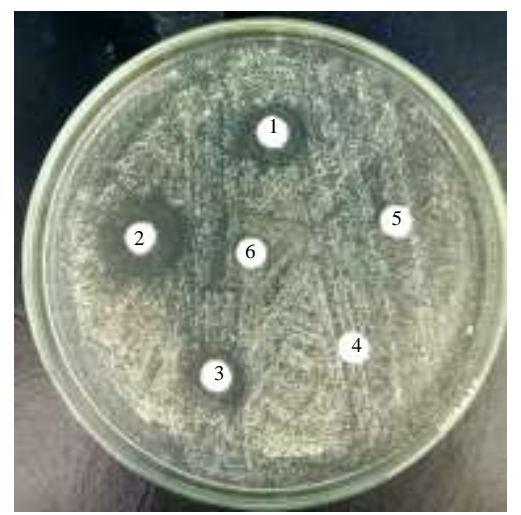

Figure 1. The inhibition zone for the growth of C. albicans by extracted Andalas endophytic bacterial product. 1-4: Extracts of Andalas endophytic bacterial fermentation products with concentrations starting from 50\%, $25 \% 12.5 \%$ and $6.5 \%$ respectively, 5: negative controls, and 6: positive controls of the result extracted antimicrobial activity toward Candida albicans.

The statistical analysis of the antifungal activity of fermetation products of Andalas endophytic bacteria showed that the extract concentration of $12.5 \%$ is the optimum concentration in inhibiting the growth of $C$. albicans. The diameter of the inhibition produced is significantly different from the diameter of the result of inhibition in positive control. This inhibition zone diameter on the growth of $C$. albicans can be seen in Table 1.

Table 1. Diameter of Inhibited Zone of extracted Andalas endophytic bacteria fermentation products against C.albicans

\begin{tabular}{cccccc}
\hline & Extract & \multicolumn{3}{c}{ Inhibition Zone Diameter $(\mathrm{cm})$} & \\
\cline { 3 - 4 } No. & $\begin{array}{c}\text { Concentratio } \\
\mathrm{n}(\%)\end{array}$ & $\mathrm{U} 1$ & $\mathrm{U} 2$ & $\mathrm{U} 3$ & Average \\
\hline 1 & $\mathrm{~K}+$ & 0,640 & 0,680 & 0,710 & $0,677^{\mathrm{c}}$ \\
2 & $6,25 \%$ & 0,000 & 0,000 & 0,000 & $0,000^{\mathrm{d}}$ \\
3 & $12,5 \%$ & 1,153 & 1,436 & 1,473 & $1,354^{\mathrm{b}}$ \\
4 & $25 \%$ & 1,483 & 2,010 & 2,367 & $1,953^{\mathrm{a}}$ \\
5 & $50 \%$ & 1,150 & 1,396 & 1,830 & $1,459^{\mathrm{b}}$ \\
\hline
\end{tabular}

The optimum concentration of extracted fermentation product from Andalas endophytic bacteria in inhibiting the growth of $S$. mutant bacteria is at extract within the concentration of $12.5 \%$. The diameter of the inhibition zone produced is significantly different from the diameter of the result of inhibition in positive control. The diameter of the inhibitory zone of extracted 
fermentation product of Andalas endophytic bacteria toward the growth of $S$. mutans bacteria in each treatment can be seen in Table 2

Tabel 2. Diameter of Inhibited Zone of extracted Andalas endophytic bacteria fermentation products against S.mutans

\begin{tabular}{cccccc}
\hline & \multirow{2}{*}{$\begin{array}{c}\text { Extract } \\
\text { No. }\end{array}$} & \multicolumn{2}{c}{ Inhibition Zone Diameter $(\mathrm{cm})$} & \\
\cline { 3 - 5 } & $\mathrm{n}(\%)$ & $\mathrm{U} 1$ & $\mathrm{U} 2$ & $\mathrm{U} 3$ & Average \\
\hline 1 & $\mathrm{~K}+$ & 0,690 & 0,680 & 0,740 & $0,703^{\mathrm{b}}$ \\
2 & $3,125 \%$ & 0,000 & 0,000 & 0,000 & $0,000^{\mathrm{c}}$ \\
3 & $6,25 \%$ & 0,000 & 0,000 & 1,280 & $0,427^{\mathrm{bc}}$ \\
4 & $12,5 \%$ & 1,330 & 1,140 & 2,200 & $1,557^{\mathrm{a}}$ \\
5 & $25 \%$ & 2,110 & 1,660 & 2,500 & $2,090^{\mathrm{a}}$ \\
6 & $50 \%$ & 2,630 & 2,180 & 2,940 & $2,583^{\mathrm{a}}$ \\
\hline
\end{tabular}

In general, the higher the concentration of the extraction the greater the antimicrobial activity produced, it is shown by the wider diameter of the microbial growth in the inhibition zone[11]. This theory is parallel with the antibacterial activity produced by the extraction's test in Table 2. However, in the antifungal activity test of extracted of fermetation products from Andalas endophytic bacteria resulted different outcome. The $50 \%$ extract concentration results in a smaller inhibition zone rather than the $25 \%$ extract concentration. This can be caused by the test method for antimicrobial activity used is the paper disk diffusion method. According to Choma (2010)[12], the principle of this method is anti-microbial compunds. This compunds are diffused in the agar to inhibit the growth of anti-microbial tested. Based on this principle, therefore, the types and the concentrations of extract can affect the ability of extract to diffuse in the agar.

The antimicrobial activity[14-17] which is resulted by the fermentation product of Andalas endophytic bacteria may cause the bacteria to have the same ability with the host plant. Based on Sturz and Nowak (2000)[4], endophytic bacteria do not cause any abnormal condition to the host plant. Moreover, according to Syah (2000)[6], Andalas has several active compunds which is characterized as antimicrobial such as morasin $B$, morasin $P$, mulberosida $C$, mulberoforan. Andalas also has some stilbert derivative compunds including oksiresveratrol, andalisin A, 2arilbenzouran derivatives, morasin $M$, coumarin derivatives, umbeliferon, and $B$-resolsilaldehid.

Afterward, it is necessary to optimize the effectiveness of extracts of Andalas endophytic bacterial fermentation products in form of medicine for mouthwash. This formulation is expected to overcome the infection problem in mouth cavity

\section{Conclusion}

Extracts of Andalas endophytic bacteria can inhibit microbial growth that causes infection in the mouth, with optimum concentration of $12.5 \%$.

\section{References}


[1] A. V. Sturz and J. Nowak, "Endophytic communities of rhizobacteria and the strategies required to create yield enhancing associations with crops," Appl. Soil Ecol., vol. 15, no. 2, pp. 183-190, 2000.

[2] G. F. Brooks, E. Jawetz, J. L. Melnick, and E. A. Adelberg, Jawetz, Melnick \& Adelberg's Medical Microbiology, vol. 53, no. 9. 2013.

[3] I. M. Choma and E. M. Grzelak, "Bioautography detection in thin-layer chromatography," Journal of Chromatography A, vol. 1218, no. 19. pp. 2684-2691, 2011.

[4] I. Nofion, Nada., Putri, Dwi Hilda., "Optimization of Medium Fermentation for Production of Antimicrobial Compounds by Endofit Bacteria Andalas Plant ( Morus macroura Miq.) B.J.T.A-6 Isolate,” vol. 2, no. 1, pp. 79-84, 2018.

[5] J. Kim and P. Sudbery, "Candida albicans, a major human fungal pathogen," Journal of Microbiology, vol. 49, no. 2. pp. 171-177, 2011.

[6] M. Cuéllar-Cruz, E. López-Romero, J. C. Villagómez-Castro, and E. Ruiz-Baca, "Candida species: New insights into biofilm formation," Future Microbiology, vol. 7, no. 6. pp. 755-771, 2012.

[7] M. F. Putri, M. Fifendy, and D. H. Putri, "Diversitas Bakteri Endofit pada Daun Muda dan Tua Tumbuhan Andaleh (Morus macroura miq.)," EKSAKTA, vol. 19, no. 1, pp. 125-130, 2018.

[8] M. Radji, "Peranan Bioteknologi dan Mikroba Endofit dalam Pengembangan Obat Herbal," Maj. Ilmu Kefarmasian, vol. 2, no. 3, pp. 113-126, 2005.

[9] N. Afifah, I. Irdawati, and D. H. Putri, "Isolation and Identification of Endophytic Bacteria from the Andalas Plant Stem ( Morus macroura Miq.)," Bioscience, vol. 2, no. 1, pp. 72-75, 2018.

[10] N. H. Soekamto, S. A. Achmad, E. L. Ghisalberti, E. H. Hakim, and Y. M. Syah, "Lunilarin And Oxyresveratrol: Two Stilbene Derivatives fraom Morus macroura," Indones. J. Chem., vol. 5, no. 3, pp. 207-210, 2010.

[11] S. Yandila, D. H. Putri, and M. Fifendy, "Endophytic Bacteria Colonization on RootAndaleh Plant ( Morus macroura Miq .)," Bio-Site, vol. 04, no. 2, pp. 1-7, 2018.

[12] Y. Farkash, M. Feldman, I. Ginsburg, D. Steinberg, and M. Shalish, "Polyphenols Inhibit Candida albicans and Streptococcus mutans Biofilm Formation,” Dent. J., vol. 7, no. 2, p. 42, 2019.

[14] Liu W, Wang L, Wang B, Xu Y, Zhu G, Lan M, et al. Diketopiperazine and Diphenylether Derivatives from Marine Algae-Derived Aspergillus versicolor OUCMDZ2738 by Epigenetic Activation. Marine drugs. 2018;17(1).

[15] Li ZJ, Yang HY, Li J, Liu X, Ye L, Kong WS, et al. Isopentylated diphenyl ether derivatives from the fermentation products of an endophytic fungus Phomopsis fukushii. The Journal of antibiotics. 2018;71(3):359-62.

[16] Ferreira MC, Cantrell CL, Wedge DE, Goncalves VN, Jacob MR, Khan S, et al. Antimycobacterial and antimalarial activities of endophytic fungi associated with the ancient and narrowly endemic neotropical plant Vellozia gigantea from Brazil. Memorias do Instituto Oswaldo Cruz. 2017;112(10):692-7.

[17] Yu FX, Chen Y, Yang YH, Li GH, Zhao PJ. A new epipolythiodioxopiperazine with antibacterial and cytotoxic activities from the endophytic fungus Chaetomium sp. M336. Natural product research. 2018;32(6):689-94. 